\title{
Effect of pulse drip irrigation and mulching systems on yield, quality traits and irrigation water use efficiency of soybean under sandy soil conditions
}

\author{
Abdelraouf Ramadan Eid ${ }^{1}$, Bakry Ahmed Bakry ${ }^{2 *}$, Moamen Hamed Taha ${ }^{3}$ \\ ${ }^{1}$ Water Relations and Field Irrigation Department, National Research Center, Giza, Egypt

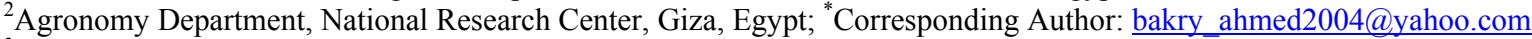 \\ ${ }^{3}$ Agronomy Department, Faculty of Agriculture, Cairo University, Giza, Egypt
}

Received 27 November 2012; revised 1 April 2013; accepted 1 May 2013

Copyright (C) 2013 Abdelraouf Ramadan Eid et al. This is an open access article distributed under the Creative Commons Attribution License, which permits unrestricted use, distribution, and reproduction in any medium, provided the original work is properly cited.

\section{ABSTRACT}

Two field experiments were carried out during growing seasons 2010 and 2011, it executed in research farm of national research center in Nubaryia region, Egypt to study the effect of pulse drip irrigation and mulching systems for saving water, increasing and improving yield of soybean. The study factors were, pulse drip irrigation technology (adding of daily water requirements on 4 times, 8 times, 12 times compared with adding of daily water requirements on 1 time) and mulching systems (covering the soil with black plastic mulch "BPM", rice straw mulch "RSM" and the control treatment was soil surface without mulch "WM"). The following parameters were studied to evaluate the effect of pulse drip irrigation and mulching systems: 1) Soil moisture distribution in root zone, 2) Growth characters of soybean plant, 3) Yield of soybean, 4) Irrigation water use efficiency of soybean "IWUE soybean", and 5) Oil content and oil yield, 6) Protein content and protein yield, 7) Economical parameter. According to the economical view and the results of statistical analysis for effect of pulse drip irrigation and mulching systems on yield, quality traits and IWUE soybean indicated that, applying the irrigation requirements on 8 pulses/day with using BPM is the best conditions because under these conditions was occurred the highest value of yield, quality traits and IWUE soybean and there was significant deference between this case and other treatments. Where, pulse irrigation technique increase from water movement in horizontal direction than vertical direction hence improve from soil moisture distribution and wetted soil volume in root zone and using BPM decrease from evaporation process rate from soil surface hence decreasing of salts accumulation in addition to decreasing of weed growth in the root zone. All traits at AIR on 12 pulses/ day are decreased by increasing of pulses, this may be due to irrigation water was very small with every pulse at AIR on 12 pulses/day in addition increasing the total time of time-off, this mean, un-sufficient application for irrigation water to remove water stress in the root zone.

Keywords: Pulse Irrigation; Mulching Systems; Water Use Efficiency; Soybean Oil and Protein

\section{INTRODUCTION}

Pulse drip irrigation technology is applied all over the world because it has positive effects on increasing yield, improving quality, saving water, and reducing from clogging emitters, etc. Pulsing irrigation refer to the practice of irrigating for a short period then waiting for another short period, and repeating this on-off cycle until the entire irrigation water is applied [1]. If the drip system drains out after each irrigation, break the irrigation down into the longest pulses possible to reduce losses to drainage. Redesign the irrigation system if the wetted area is too small (limiting) and pulsing is not an option [2].

Based on reports from other states (where soil types are different), it is often believed that the size of the wetted zone can be increased if irrigation is pulsed [1]. Pulse irrigation system, irrigating amount and timing are the objectives for reducing run off, decreasing percolation of water beneath the root zone and reducing water evapora- 
tion after irrigation [3]. Applying irrigation water in stages or pulses rather than all at one time can save water by giving the media time to moisten from the first pulse of water thereby allowing it to absorb subsequent irrigation more readily and reducing the total amount of water required [4]. High irrigation frequency might provide desirable conditions for water movement in soil and for uptake by roots [5].

Continuous water application is associated with increased water percolation under root zone. Intermittent irrigation strategy based on discharge pulses followed by breaks could improve water management in the field and increase irrigation efficiency [6]. [5,7] reported that high frequency or long lasting, low discharge irrigation can increase water use and yields of crops by providing desirable conditions for water movement in soil and for uptake by roots. As soil water conditions become more constant, plants are able to utilize water and increase production. Further study is necessary to evaluate these finding on other crops and to develop economically feasible methods for low discharge and high frequency irrigation. The studies resulted in the fact that, under the experiment alternatives with low-volume pulse water application close to the evapotranspiration, the yields of cultivated crops (clover, rye grass, timothy, fescue, tip onion, lettuce) were usually $1.3-2.5$ times higher than the yields of crops grown under traditional regular irrigation [8].

Mulch is a protective layer of either organic or inorganic material that is spread on the top soil to: 1) reduce the moisture loss from the soil by preventing evaporation from sunshine and desiccating winds, 2) prevent weed growth, 3) improve soil condition, 4) provide home for earthworms and natural enemies found in the soil, 5) reduce soil compaction from the impact of heavy rains. Mulch helps regulate soil temperature by shading it in the summer thus keeping it cooler and helps insulate it in the winter from chilling winds. This temperature regulating effect helps encourage the root growth of plants, and prevent soil erosion [9]. Agriculture with mulch in the tropics promotes plant health and vigor. Mulching improves nutrient and water retention in the soil, encourages favorable soil microbial activity and worms, and suppresses weed growth. When properly executed, mulching can significantly improve the well-being of plants and reduce maintenance as compared to bare soil culture. Mulched plants have better vigor and, consequently have improved resistance to pests and diseases [10]. Using plastic mulches at 200 and $150 \mathrm{~mm}$, two layers of cattail or rice straw mulch, and hand hoeing for controlling weeds resulted in the highest yield per tree without significant differences between these treatments [11]. Soybean (Glycine max) is one of the most important world crops and is grown for oil and protein. Present world production is about 176.6 million tons of beans over 75.5 million ha. The crop is mainly grown under rain fed conditions but irrigation, specifically supplemental irrigation, is increasingly used [12].

The objective of this study was to investigate the effect of pulse drip irrigation and mulching systems for increasing yield, irrigation water use efficiency and improvement of quality traits for soybean crop in arid and semi-arid regions.

\section{MATERIALS AND METHODS}

\subsection{Site Description}

Field experiments were conducted during two wheat seasons from May to September of 2010-2011 at the experimental farm of National Research Center, El-Nubaria, Egypt (latitude $30.8667 \mathrm{~N}$, and longitude $31.1667 \mathrm{E}$, and mean altitude $21 \mathrm{~m}$ above sea level). The experimental area has an arid climate with cool winters and hot dry summers prevailing in the experimental area. Table 1 summarizes the monthly mean climatic data for the two growing seasons 2010 and 2011, respectively, for ElNubaria city, which are nearly the same. The data of maximum and minimum temperature, relative humidity, and wind speed were obtained from "weather station inside the farm". There was not rainfall that could be taken into consideration through the two seasons, because the amount was very little and the duration didn't exceed few minutes.

Estimation the seasonal irrigation water for soybean plant (Giza 111): seasonal irrigation water was estimated according to the meteorological data of the Central La-

Table 1. Summarizes the monthly mean climatic data for the two growing seasons 2010 and 2011, for El-Nubaria city.

\begin{tabular}{|c|c|c|c|c|c|}
\hline \multirow{3}{*}{ Date } & Precipitation & \multicolumn{3}{|c|}{$\mathrm{HC}$ air temperature } & \multirow{2}{*}{$\begin{array}{c}\text { HC relative } \\
\text { humidity }\end{array}$} \\
\hline & {$[\mathrm{mm}]$} & & {$\left[{ }^{\circ} \mathrm{C}\right]$} & & \\
\hline & sum & average & minimum & maximum & average \\
\hline May/2010 & 0.0 & 21.4 & 15.4 & 28.8 & 65.8 \\
\hline Jun/2010 & 0.0 & 24.3 & 18.7 & 30.5 & 69.6 \\
\hline $\mathrm{Jul} / 2010$ & 0.19 & 26.63 & 20.62 & 33.19 & 73.16 \\
\hline Aug/2010 & 0.1 & 26.4 & 20.5 & 32.8 & 73.2 \\
\hline $\mathrm{Sep} / 2010$ & 0.19 & 25.06 & 19.05 & 32.22 & 75.13 \\
\hline May/2011 & 0.05 & 22.46 & 15.65 & 30.72 & 73.81 \\
\hline Jun/2011 & 0.0 & 25.3 & 19.6 & 31.9 & 80.2 \\
\hline Jul/2011 & 0.0 & 27.7 & 22.1 & 33.8 & 80.1 \\
\hline Aug/2011 & 0.0 & 27.5 & 21.7 & 34.1 & 79.6 \\
\hline Sep/2011 & 0.00 & 24.99 & 19.34 & 31.51 & 80.20 \\
\hline
\end{tabular}


boratory for Agricultural Climate (CLAC) depending on Penman-Monteith equation was shown in Figure 1, the seasonal irrigation water applied was found $3385 \mathrm{~m}^{3} / \mathrm{fed}$.

\subsection{Soil Physical and Chemical Properties}

Properties of soil and irrigation water for experimental site are presented in Tables 2-4.

\subsection{Irrigation System Components}

Irrigation system components consisted of control head, pumping and filtration unit. It consists of submersible pump with $45 \mathrm{~m}^{3} / \mathrm{h}$ discharge and it was driven by electrical engine and screen filter and back flow preven

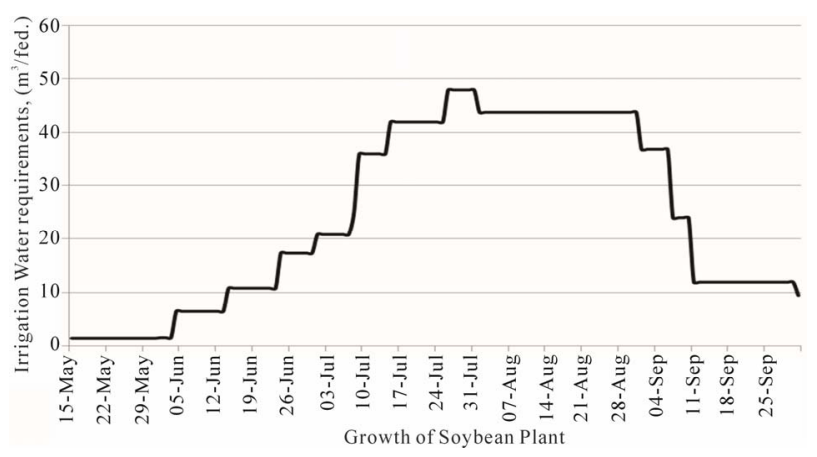

Figure 1. The relation between growth of soybean plant and irrigation water requirements.

Table 2. Chemical and mechanical analyses of soil.

\begin{tabular}{|c|c|c|c|c|c|c|c|c|}
\hline \multirow{2}{*}{ Depth } & \multirow[b]{2}{*}{$\begin{array}{l}\mathrm{OM} \\
(\%)\end{array}$} & \multicolumn{3}{|c|}{ Chemical analysis } & \multicolumn{3}{|c|}{ Mechanical analysis } & $\stackrel{0}{0}$ \\
\hline & & $\begin{array}{c}\mathrm{pH} \\
(1: 2.5)\end{array}$ & $\begin{array}{c}\mathrm{EC} \\
\left(\mathrm{dSm}^{-1}\right)\end{array}$ & $\begin{array}{c}\mathrm{CaCO}_{3} \\
\%\end{array}$ & $\begin{array}{c}\text { Course } \\
\text { sand }\end{array}$ & $\begin{array}{l}\text { Fine } \\
\text { sand }\end{array}$ & Clay + Silt & \\
\hline $0-20$ & 0.65 & 8.7 & 0.35 & 7.02 & 47.76 & 49.75 & 2.49 & \\
\hline $20-40$ & 0.40 & 8.8 & 0.32 & 2.34 & 56.72 & 39.56 & 3.72 & \\
\hline $40-60$ & 0.25 & 9.3 & 0.44 & 4.68 & 36.76 & 59.40 & 3.84 & \\
\hline
\end{tabular}

Table 3. Characteristics of soil.

\begin{tabular}{cccccc}
\hline Depth & SP (\%) & F.C (\%) & W.P (\%) & A.W (\%) & $\begin{array}{c}\text { Hydraulic } \\
\text { conductivity (cm/hr) }\end{array}$ \\
\cline { 2 - 4 } $0-20$ & 21.0 & 10.1 & 4.7 & 5.4 & 22.5 \\
$20-40$ & 19.0 & 13.5 & 5.6 & 7.9 & 19.0 \\
$40-60$ & 22.0 & 12.5 & 4.6 & 7.9 & 21.0 \\
\hline
\end{tabular}

Table 4. Chemical characteristics of irrigation water.

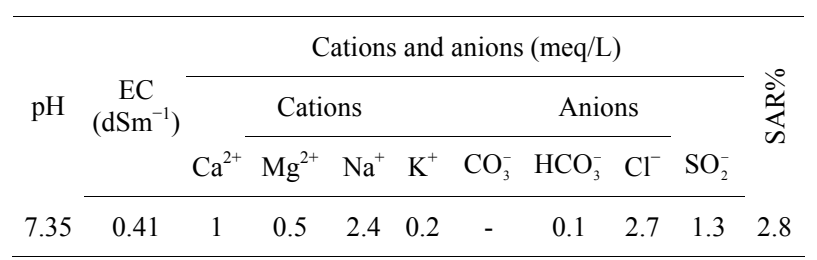

tion device, pressure regulator, pressure gauges, flowmeter, control valves. Main line was of PVC pipes with $110 \mathrm{~mm}$ in diameter (OD) to convey the water from the source to the main control points in the field. Sub-main lines were of PVC pipes with $75 \mathrm{~mm}$ diameter (OD) was connected to the main line. Manifold lines: PE pipes were of $63 \mathrm{~mm}$ in diameter (OD) was connected to the sub main line through control valve 2 and discharge gauge. Emitters, built in laterals tubes of PE with $16 \mathrm{~mm}$ diameter (OD) and $30 \mathrm{~m}$ in long emitter discharge was 4 lph at 1.0 bar operating pressure and $30 \mathrm{~cm}$ spacing between emitters.

\subsection{Components of Mulch}

2 layers of rice straw mulch $(6 \mathrm{~cm}$ deep $)=15$ tons $/$ ha and black Plastic mulch (BPM) $200 \mathrm{~mm}$ thickness was used.

\subsection{Experimental Design}

Experimental design and treatments was split plot with three replications. Pulse drip irrigation (adding of daily water requirements on 4 times, 8 times, 12 times compared with adding of daily water requirements on 1 time) in main plots and mulching systems (covering the soil with black plastic mulch, rice straw mulch and the control treatment was soil surface without mulch) in submain plots.

\subsection{Methods}

Soil moisture content was determined according to [13]. The soil samples were taken at maximum actual water requirements by profile probe before and 2 hours after irrigation and from different locations. In the case of $30 \mathrm{~cm}$ emitter space the sample locations were at 5,10 , and $15 \mathrm{~cm}$ on the X-direction (space between the emitters). For each of these locations, soil samples were collected from different depths from soil surface, which were $0,15,30$ and $45 \mathrm{~cm}$ on the Y-direction. By using "contouring program Surfer version 8", we obtained on contouring maps for different moisture levels with depths.

Irrigation water use efficiency of Soybean crop (IWUE $E_{\text {Soybean crop }}$ was calculated according to [14] as follows: IWUE $E_{\text {Soybean crop }}\left(\mathrm{kg}_{\text {grain }} / \mathrm{m}^{3}\right.$ water $)=$ Total yield, $\left(\mathrm{kg}_{\text {grain }} / \mathrm{fed}\right.$. $) /$ Total applied irrigation water, $\left(\mathrm{m}^{3}\right.$ water $/ \mathrm{fed}$./ season).

Leaf area $=$ leaf length $\times$ maximum leaf width $\times 0.75$ according to [15] and chlorophyll content was estimated by Span device.

Costs of mulching materials LE/fed., 1) cost of rice straw mulch $=$ price of rice straw + cost of transport of rice straw + Labor, 2) cost of black plastic mulch $=$ price of black plastic sheet + cost of transport of black plastic 
sheet + Labor, and 3) cost with no mulch $=$ cost of weed control.

Seed oil \%: was determined by soxhlet apparatus using petroleum ether $\left(40^{\circ} \mathrm{C}-60^{\circ} \mathrm{C}\right.$ b.p $)$ according to [16] and oil yield $(\mathrm{kg} / \mathrm{fed})$ was calculated by seed yield $(\mathrm{kg} / \mathrm{fed}) \times$ seed oil $(\%)$.

Total $\mathrm{N}$-content in seeds determined and protein $\%$ was calculated by multiplying $\mathrm{N}$-content by 6.25 according to [17], protein yield/fed. Calculated by multiply protein $\% \times$ seed yield $/$ fed.

Statistical analysis: the standard analysis of variance procedure of split-split plot design with three replications as described by [18] was used. All data were calculated from combined analysis for the two growing seasons 2010 and 2011. The treatments were compared according to L.S.D. test at 5\% level of significance.

\section{RESULTS AND DISCUSSION}

\subsection{Soil Moisture Distribution in Root Zone}

Figures 2-4 indicated the effect of number of irrigation pulses and mulching systems on soil moisture distribution in the root zone (SMDRZ). SMDRZ is improved after irrigation and before the next irrigation by increasing number of irrigation pulses per day than applying of irrigation requirements continuously (AIRC) and applying of irrigation requirements (AIR) on 12 pulses.

SMDRZ is improved also with using black plastic mulch (BPM) and rice straw mulch (RSM) respectively compared with control treatment (without mulch "WM"). Increasing of SMDRZ by increasing number of irrigation pulses this may be due to increasing number of pulses will increase from water movement in horizontal direction than vertical direction. These results are agreement with those obtained by [1,2,6,19-21]. Not only SMDRZ is improved by increasing number of pulses but also wetted soil volume (more than or equal field capacity "WSV $\mathrm{WFC}_{\geq \mathrm{FC}}$ ) is increased. Increasing of $\mathrm{WSV}_{\geq \mathrm{FC}}$ in the root zone will increase from volume of available water in root zone.

$\mathrm{WSV}_{\geq \mathrm{FC}}$ decreased after AIR on 12 pulses this due to apply small amount of irrigation water with more pulses with increasing in time-off will decreased from $\mathrm{WSV}_{\geq \mathrm{FC}}$. Improving of SMDRZ with using BPM and RSM compared with without mulch this may be due to increase of initial moisture content before irrigation. Increasing of initial moisture content in the root zone before the irrigation occurred with using BPM and RSM only this due to decrease in evaporation process from soil surface.

\subsection{Growth Characters of Soybean Plant}

Data illustrated in Table 5 shows the effect of number of irrigation pulses and mulching systems on the main growth parameters of soybean plants. Effect of the first factor (pulse irrigation technique) on main growth parameters of soybean plants was positive and significant where, the highest values of growth parameters occurred by AIR on 4 pulses and 8 pulses respectively. Effect of the second factor (mulching systems) on main growth parameters of soybean plants also was positive and significant where, the highest values of growth parameters occurred by using BPM and RSM respectively compared with control treatment (without mulch).

Table 5 shows clearly that the effect of interaction between pulse drip irrigation and mulching systems on main growth parameters of soybean plants also was positive and significant where, the highest values of growth parameters occurred by AIR on 8 pulses per day and using BPM. Increasing the values of growth parameters by AIR on 8 pulses per day and using BPM this may be due to improve in SMDRZ and increasing of $\mathrm{WSV}_{\geq \mathrm{FC}}$ in the root zone and using BPM will decrease from evaporation process from soil surface and salt accumulation. These results are agreement with those obtained by [22].

\subsection{Seed Yield of Soybean}

Seed yield is the main goal from any development in agriculture. Table 6 shows the effect of number of irrigation pulses and mulching systems on soybean yield.

Effect of the first factor (pulse irrigation technique) on soybean yield was positive and significant where, the highest values of soybean yield were 1.67 (ton/fed.) and 1.61 (ton/fed.) occurred by AIR on 4 pulses and 8 pulses respectively and there are no significant deference between AIR on 4 pulses and 8 pulses.

Effect of the second factor (mulching systems) on soybean yield also was positive and significant where, the highest value of soybean yield was 1.71 (ton/fed.) occurred by using BPM and there are significant deference between using BPM and other treatments.

Figure 5 and Table 6 show the effect of interaction between pulse drip irrigation and mulching systems on soybean yield. The highest value of soybean yield was 2.2 (ton/fed.) occurred by using AIR on 8 pulses per day and using BPM and there are significant deference between theses conditions and other treatments. Increasing the value of soybean yield by AIR on 8 pulses per day and using BPM this may be due to the increasing in the available nutrients in the root zone and these nutrients will be more available for plant by improvement of SMDRZ and increasing of $\mathrm{WSV}_{\geq \mathrm{FC}}$ in the root zone and also using BPM will decrease from evaporation process from soil surface and salt accumulation. In general, values of soybean yield increased by increasing number of irrigation pulses under BPM and RSM until AIR on 8 pulses/day and than values of soybean yield decreased at AIR on 12 pulses/day, this may be due to irrigation water 

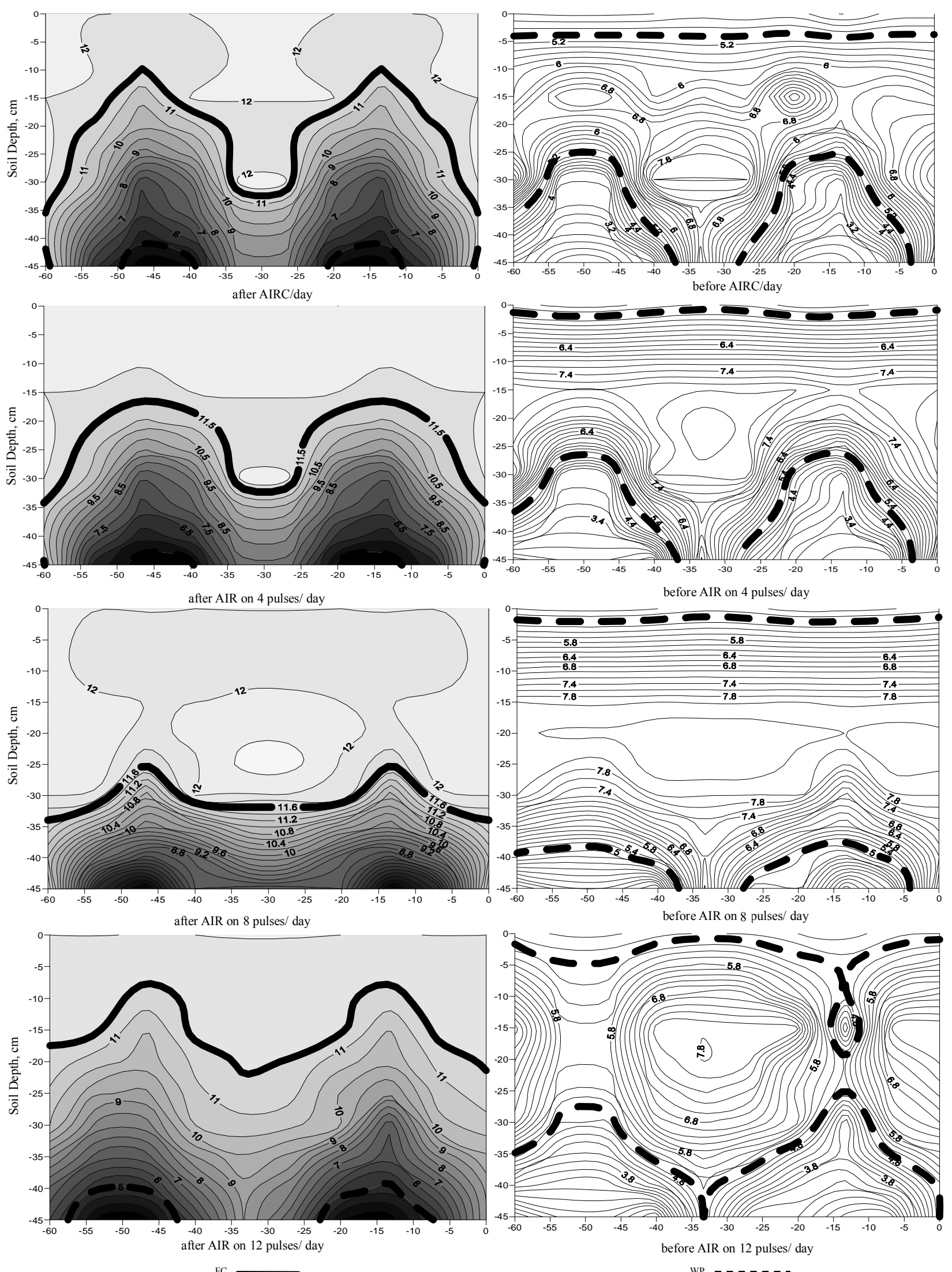

Figure 2. Soil moisture distribution without mulch. AIRC: Appling of Irrigation Requirements Continuously. 

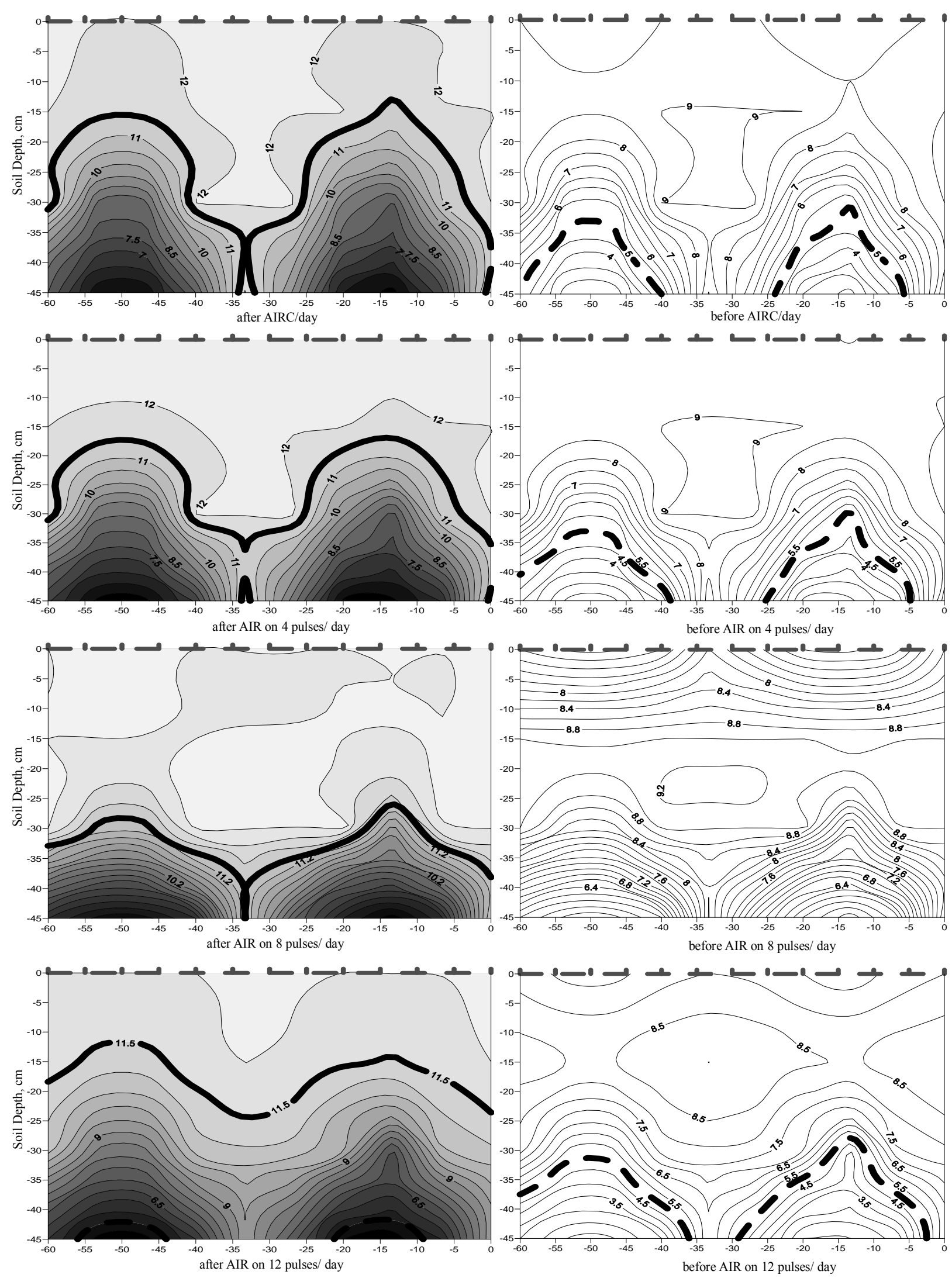

Figure 3. Soil moisture distribution rice straw mulch. AIRC: Appling of Irrigation Requirements Continuously. 

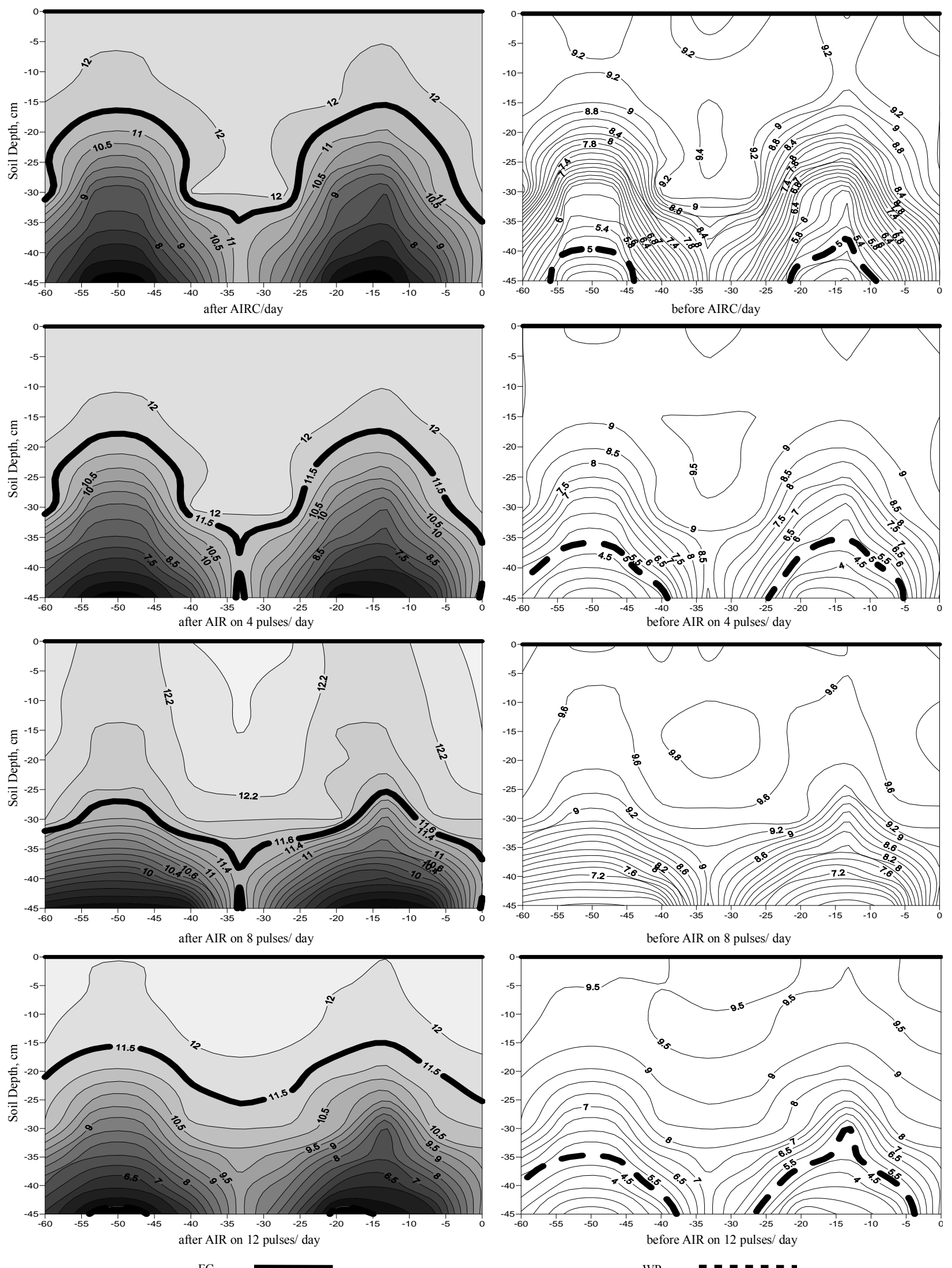

WP

- घ घ घ घ

Figure 4. Soil moisture distribution black plastic mulch. AIRC: Appling of Irrigation Requirements Continuously. 


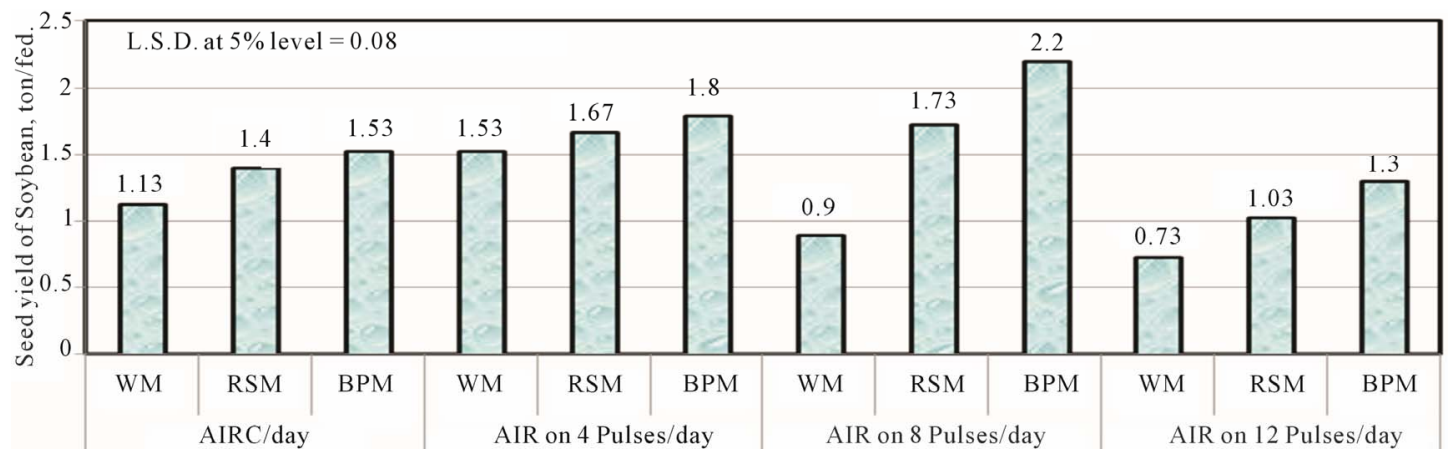

Figure 5. Interaction between pulse drip irrigation and mulching systems on seed yield of soybean.

Table 5. Effect of experimental treatments on the wheat growth parameters.

\begin{tabular}{|c|c|c|c|c|}
\hline & & $\begin{array}{c}\text { Dry } \\
\text { eight/ plant, (g) }\end{array}$ & $\begin{array}{c}\text { Leaves } \\
\text { area/plant, } \mathrm{cm}^{2}\end{array}$ & $\begin{array}{c}\text { Chlorophyll } \\
\text { content, \% }\end{array}$ \\
\hline \multicolumn{5}{|c|}{ Pulsed drip irrigation technique } \\
\hline \multicolumn{2}{|c|}{ AIRC/day } & 103.89 & 5876.3 & 30.61 \\
\hline \multicolumn{2}{|c|}{ AIR on 4 pulses/day } & 112.67 & 6328 & 37.80 \\
\hline \multicolumn{2}{|c|}{ AIR on 8 pulses/day } & 111.22 & 6178 & 36.16 \\
\hline \multicolumn{2}{|c|}{ AIR on 12 pulses/day } & 94.11 & 5539.2 & 24.51 \\
\hline \multicolumn{2}{|c|}{ L.S.D. at $5 \%$ level } & 2.35 & 13.72 & 0.61 \\
\hline \multicolumn{5}{|c|}{ Mulching systems } \\
\hline \multicolumn{2}{|c|}{ WM } & 97.42 & 5558.3 & 25.98 \\
\hline \multicolumn{2}{|c|}{ RSM } & 107.75 & 5921.8 & 33.02 \\
\hline \multicolumn{2}{|c|}{ BPM } & 111.25 & 6461 & 37.81 \\
\hline \multicolumn{2}{|c|}{ L.S.D. at $5 \%$ level } & 2.47 & 8.49 & 0.81 \\
\hline \multicolumn{5}{|c|}{ Interaction between pulse drip irrigation and mulching systems } \\
\hline & WM & 100.33 & 5825.3 & 27.20 \\
\hline \multirow[t]{3}{*}{ AIRC/day } & RSM & 105.00 & 5887.3 & 31.67 \\
\hline & BPM & 106.33 & 5916.3 & 32.97 \\
\hline & WM & 110.33 & 5954.3 & 34.33 \\
\hline \multirow[t]{3}{*}{$\begin{array}{l}\text { AIR on } 4 \\
\text { pulses/day }\end{array}$} & RSM & 112.00 & 6007.7 & 36.33 \\
\hline & BPM & 115.67 & 7022.0 & 43.03 \\
\hline & WM & 99.00 & 5434.0 & 23.03 \\
\hline \multirow[t]{3}{*}{$\begin{array}{c}\text { AIR on } 8 \\
\text { pulses/day }\end{array}$} & RSM & 114.33 & 6045.0 & 40.03 \\
\hline & BPM & 120.33 & 7055.0 & 45.40 \\
\hline & WM & 80.00 & 5020.0 & 19.67 \\
\hline \multirow[t]{2}{*}{$\begin{array}{l}\text { AIR on } 12 \\
\text { pulses/day }\end{array}$} & RSM & 99.67 & 5747.0 & 24.03 \\
\hline & BPM & 102.67 & 5850.7 & 29.83 \\
\hline \multicolumn{2}{|c|}{ L.S.D. at $5 \%$ level } & 4.95 & 16.98 & 0.61 \\
\hline
\end{tabular}

RSM: Rice Straw Mulch, BPM: Black Plastic Mulch, WM: Without Mulch, AIRC: Appling of Irrigation Requirements Continuously, AIR: Appling of Irrigation Requirements. was very small with every pulse at AIR on 12 pulses/day in addition increasing the number of time-off and this mean, un-sufficient application for irrigation water to remove water stress in the root zone. Under no mulch and after AIR on 4 pulses/day, the values of soybean yield decreased by increasing number of irrigation pulses this may be due to increasing of evaporation process rate from soil surface by increasing number of irrigation pulses and increasing of time-off, this mean, concentration the salts around the plant which increase from osmotic potentional, hence increasing in probability of plasmolysis (loss of water through osmosis is accompanied by shrinkage of protoplasm away from the cell wall) hence decreasing from yield of soybean.

\subsection{Irrigation Water Use Efficiency}

Irrigation water use efficiency is the main goal from any development in agriculture is saving water. Table 6 shows the effect of number of irrigation pulses and mulching systems on IWUE $E_{\text {Soybean }}$.

Effect of the first factor (pulse irrigation technique) on IWUE $_{\text {Soybean }}$ was positive and significant where, the highest values of IWUE $E_{\text {Soybean }}$ were $0.478\left(\mathrm{~kg}_{\text {seed }} / \mathrm{m}^{3}\right.$ water $)$ occurred by AIR on 4 pulses and 8 pulses and there are no significant deference between AIR on 4 pulses and 8 pulses.

Effect of the second factor (mulching systems) on IWUE $_{\text {Soybean }}$ also was positive and significant where, the highest value of IWUE Soybean was $0.492\left(\mathrm{~kg}_{\text {seed }} / \mathrm{m}^{3}\right.$ water $)$ occurred by using BPM and there are significant deference between using BPM and other treatments.

Figure 6 and Table 6 clearly that the effects of interaction between pulse drip irrigation and mulching systems on IWUE $E_{\text {Soybean. }}$. The highest value of IWUE Soybean was $0.633\left(\mathrm{~kg}_{\text {seed }} / \mathrm{m}^{3}\right.$ water $)$ occurred by using AIR on 8 pulses per day and using BPM and there are no significant deference between these conditions and other treatments. Increasing the value of IWUE Soybean $_{\text {by }}$ AIR on 8 pulses per day and using BPM this due to the increasing in soybean yield and this mean, the highest value of soybean yield (2.2 ton/fed.) occurred under AIR on 


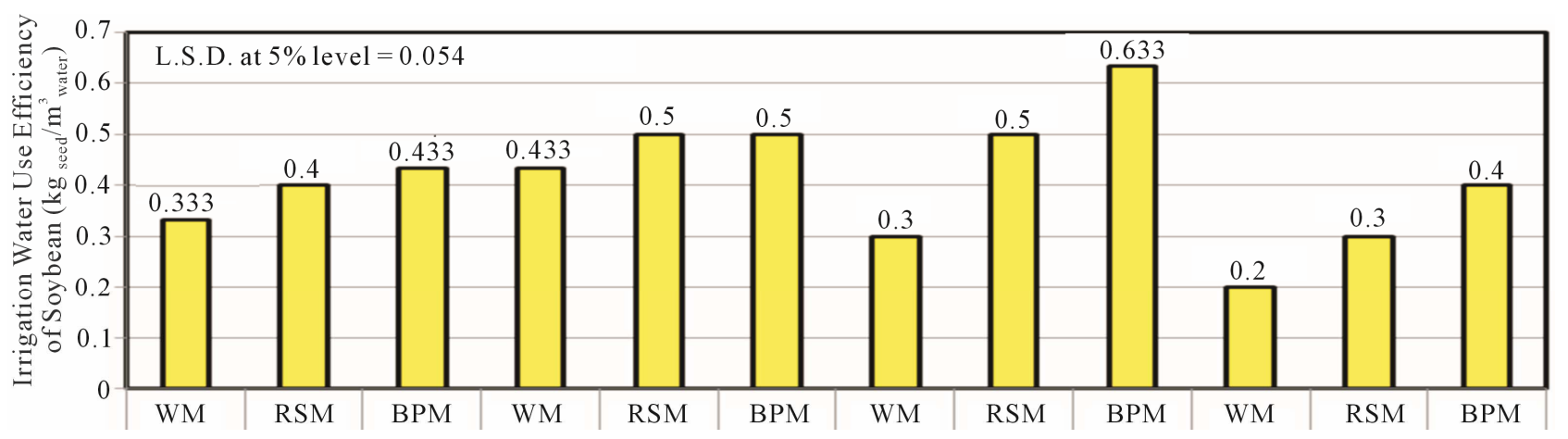

Figure 6. Interaction between pulse drip irrigation and mulching systems on irrigation water use efficiency of soybean.

Table 6. Effect of experimental treatments on the soybean yield and irrigation water use efficiency.

\begin{tabular}{|c|c|c|c|}
\hline \multicolumn{3}{|c|}{ Seed yield, ton/fed. } & \multirow{2}{*}{ IWUE ${ }_{\text {Soybean, }}, \mathrm{kg}_{\text {seed }} / \mathrm{m}_{\text {water }}^{3}$} \\
\hline \multicolumn{3}{|c|}{ Pulsed drip irrigation technique } & \\
\hline $\mathrm{AIRC} / \mathrm{da}$ & & 1.36 & 0.389 \\
\hline AIR on 4 Pulse & & 1.67 & 0.478 \\
\hline AIR on 8 Pulse & & 1.61 & 0.478 \\
\hline AIR on 12 Puls & & 1.02 & 0.300 \\
\hline L.S.D. at $5 \%$ & & 0.06 & 0.051 \\
\hline \multicolumn{4}{|c|}{ Mulching systems } \\
\hline WM & & 1.08 & 0.317 \\
\hline RSM & & 1.46 & 0.425 \\
\hline BPM & & 1.71 & 0.492 \\
\hline \multicolumn{2}{|c|}{ L.S.D. at $5 \%$ level } & 0.04 & 0.027 \\
\hline \multicolumn{4}{|c|}{ Interaction between pulse drip irrigation and mulching systems } \\
\hline \multirow{3}{*}{ AIRC / day } & WM & 1.13 & 0.333 \\
\hline & RSM & 1.40 & 0.400 \\
\hline & BPM & 1.53 & 0.433 \\
\hline \multirow{3}{*}{ AIR on 4 Pulses/ day } & WM & 1.53 & 0.433 \\
\hline & RSM & 1.67 & 0.500 \\
\hline & BPM & 1.80 & 0.500 \\
\hline \multirow{3}{*}{ AIR on 8 Pulses/ day } & WM & 0.90 & 0.300 \\
\hline & RSM & 1.73 & 0.500 \\
\hline & BPM & 2.20 & 0.633 \\
\hline \multirow{3}{*}{ AIR on 12 Pulses/ day } & WM & 0.73 & 0.200 \\
\hline & RSM & 1.03 & 0.300 \\
\hline & BPM & 1.30 & 0.400 \\
\hline \multicolumn{2}{|c|}{ L.S.D. at $5 \%$ level } & 0.08 & 0.054 \\
\hline
\end{tabular}

RSM: Rice Straw Mulch, BPM: Black Plastic Mulch, WM: Without Mulch, AIRC: Appling of Irrigation Requirements Continuously, AIR: Appling of Irrigation Requirements. 
8 pulses per day and using BPM compared with (1.13 ton/fed.) under AIRC/day and without mulch (control treatment) under the same amount of irrigation water this mean, increasing degree in the yield was $50 \%$ which equal 1.07 ton/fed.

\subsection{Oil Content and Oil Yield}

Table 7 shows the effect of number of irrigation pulses and mulching systems on oil content and oil yield of

Table 7. Effect of experimental treatments on the oil content, oil yield, protein content and protein yield.

\begin{tabular}{|c|c|c|c|c|c|c|}
\hline & & $\begin{array}{l}\text { Seed yield, } \\
\text { ton/fed. }\end{array}$ & $\begin{array}{c}\text { Oil } \\
\text { content, } \\
\%\end{array}$ & $\begin{array}{c}\text { Oil } \\
\text { yield, } \\
\mathrm{kg} / \text { fed. }\end{array}$ & $\begin{array}{c}\text { Protein } \\
\text { content, } \\
\%\end{array}$ & $\begin{array}{l}\text { Protein } \\
\text { yield, } \\
\mathrm{kg} / \text { fed. }\end{array}$ \\
\hline \multicolumn{7}{|c|}{ Pulsed drip irrigation technique } \\
\hline \multicolumn{2}{|c|}{ AIRC/day } & 1.36 & 17.69 & 240.58 & 29.38 & 399.57 \\
\hline \multicolumn{2}{|c|}{ AIR on 4 pulses/day } & 1.67 & 19.77 & 330.16 & 34.53 & 576.65 \\
\hline \multicolumn{2}{|c|}{ AIR on 8 pulses/day } & 1.61 & 19.37 & 311.86 & 34.73 & 559.15 \\
\hline \multicolumn{2}{|c|}{ AIR on 12 pulses/day } & 1.02 & 16.04 & 163.61 & 25.09 & 255.92 \\
\hline \multicolumn{2}{|c|}{ L.S.D. at $5 \%$ level } & 0.06 & 0.5 & 14.36 & 1 & 26.02 \\
\hline \multicolumn{7}{|c|}{ Mulching systems } \\
\hline \multicolumn{2}{|l|}{ WM } & 1.08 & 16.94 & 182.95 & 28.38 & 306.50 \\
\hline \multicolumn{2}{|l|}{ RSM } & 1.46 & 18.26 & 266.60 & 31.02 & 452.89 \\
\hline \multicolumn{2}{|l|}{ BPM } & 1.71 & 19.45 & 332.60 & 33.4 & 571.14 \\
\hline \multicolumn{2}{|c|}{ L.S.D. at $5 \%$ level } & 0.04 & 0.57 & 8.1 & 1.14 & 15.09 \\
\hline \multicolumn{7}{|c|}{ Interaction between pulse drip irrigation and mulching systems } \\
\hline & WM & 1.13 & 16.97 & 191.76 & 27.93 & 315.61 \\
\hline \multirow[t]{3}{*}{ AIRC/day } & RSM & 1.40 & 17.7 & 247.80 & 29.4 & 411.60 \\
\hline & BPM & 1.53 & 18.4 & 281.52 & 30.8 & 471.24 \\
\hline & WM & 1.53 & 18.6 & 284.58 & 32.2 & 492.66 \\
\hline \multirow[t]{3}{*}{$\begin{array}{c}\text { AIR on } 4 \\
\text { pulses/day }\end{array}$} & RSM & 1.67 & 20.07 & 335.17 & 35.13 & 586.67 \\
\hline & BPM & 1.80 & 20.63 & 371.34 & 36.27 & 652.86 \\
\hline & WM & 0.90 & 16.63 & 149.67 & 29.27 & 263.43 \\
\hline \multirow[t]{3}{*}{$\begin{array}{c}\text { AIR on } 8 \\
\text { pulses/day }\end{array}$} & RSM & 1.73 & 19.87 & 343.75 & 35.73 & 618.13 \\
\hline & BPM & 2.20 & 21.6 & 475.20 & 39.2 & 862.40 \\
\hline & WM & 0.73 & 15.57 & 113.66 & 24.13 & 176.15 \\
\hline \multirow[t]{2}{*}{$\begin{array}{l}\text { AIR on } 12 \\
\text { pulses/day }\end{array}$} & RSM & 1.03 & 15.4 & 158.62 & 23.8 & 245.14 \\
\hline & BPM & 1.30 & 17.17 & 223.21 & 27.33 & 355.29 \\
\hline \multicolumn{2}{|c|}{ L.S.D. at $5 \%$ level } & 0.08 & 1.31 & 18.07 & 2.63 & 34.84 \\
\hline
\end{tabular}

RSM: Rice Straw Mulch, BPM: Black Plastic Mulch, WM: Without Mulch, AIRC: Appling of Irrigation Requirements Continuously, AIR: Appling of Irrigation Requirements. soybean.

Effect of the first factor (pulse irrigation technique) on the oil content was positive and significant where, the highest values of oil content were $19.77 \%$ and $19.37 \%$ occurred by AIR on 4 pulses and 8 pulses respectively and there are no significant deference between AIR on 4 pulses and 8 pulses. But there is significant deference between the highest values of oil yield.

Effect of the second factor (mulching systems) on oil content and oil yield of soybean also was positive and significant where, the highest value of oil content and oil yield was $19.45 \%$ and 332.60 (kg/fed.) occurred by using BPM and there are significant deference between using BPM and other treatments.

Figure 7 and Table 7 clearly that the effect of interaction between pulse drip irrigation and mulching systems on oil content and oil yield of soybean. The highest value of oil content and oil yield of soybean was $21.6 \%$ and 475.20 respectively occurred by using AIR on 8 pulses per day and using BPM and there are significant deference between theses conditions and other treatments. Increasing the value of oil content and oil yield by AIR on 8 pulses per day and using BPM this may be due to the increasing in the available nutrients in the root zone and these nutrients will be more available for plant by improvement of SMDRZ and increasing of $\mathrm{WSV}_{>\mathrm{FC}}$ in the root zone and also using BPM will decrease from salt accumulation.

\subsection{Protein Content and Protein Yield}

Table 7 shows the effect of number of irrigation pulses and mulching systems on protein content and protein yield of soybean.

Effect of the first factor (pulse irrigation technique) on the protein content was positive and significant where, the highest values of protein content were $34.73 \%$ and $34.53 \%$ occurred by AIR on 8 pulses and 4 pulses respectively and there are no significant deference between AIR on 8 pulses and 4 pulses. The highest values of protein yield were 576.65 and 559.15 (kg/fed.) occurred by AIR on 4 pulses and 8 pulses respectively and there are no significant deference between AIR on 4 pulses and 8 pulses.

Effect of the second factor (mulching systems) on protein content and protein yield of soybean also was positive and significant where, the highest value of protein content and protein yield was $33.4 \%$ and 571.14 (kg/fed.) occurred by using BPM and there are significant deference between using BPM and other treatments.

Figure 8 and Table 7 clearly that the effect of interaction between pulse drip irrigation and mulching systems on protein content and protein yield of soybean. The highest value of protein content and protein yield was $39.2 \%$ and $862.40(\mathrm{~kg} / \mathrm{fed}$.) respectively occurred by using AIR on 8 pulses per day and using BPM and there 
are significant deference between theses conditions and other treatments. Increasing the value of oil content and oil yield by AIR on 8 pulses per day and using BPM this may be due to the increasing in the available nutrients in the root zone and these nutrients will be more available for plant by improvement of SMDRZ and increasing of $\mathrm{WSV}_{\geq \mathrm{FC}}$ in the root zone and also using BPM will decrease from salt accumulation.

\subsection{Economical Parameter}

Figure 9 and Table 8 clearly that the effects of interaction between pulse drip irrigation and mulching systems on costs of mulching and total income ${ }^{-\mathrm{CMP} \text { (costs of }}$ mulching process) where, total income $\mathrm{e}^{-\mathrm{CMP}}=$ total income costs of mulching process only. The highest value of total income $^{-\mathrm{CMP}}$ was $8660 \mathrm{LE} /$ fed occurred by using AIR on

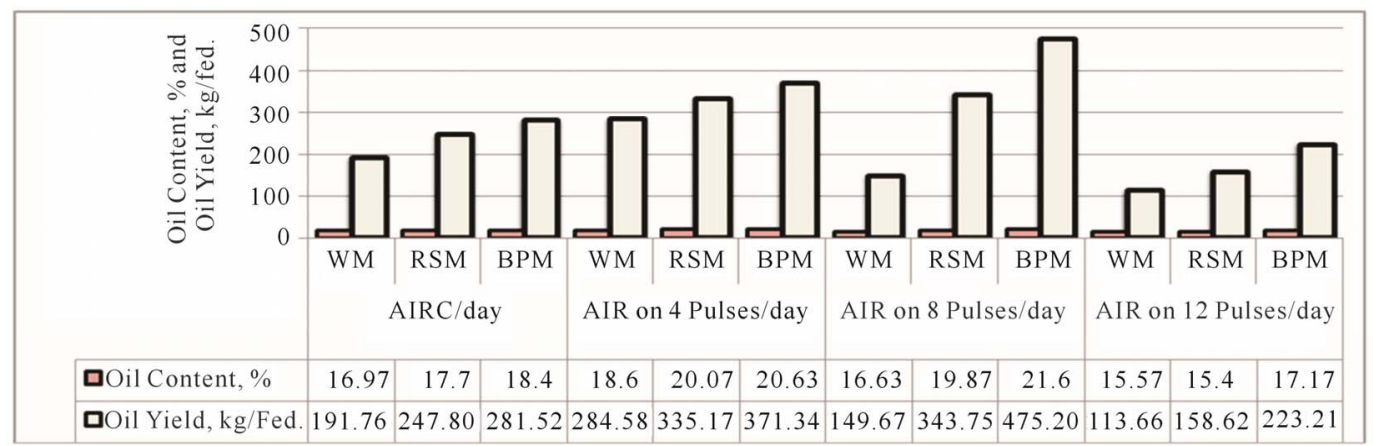

Figure 7. Interaction between pulse drip irrigation and mulching systems on oil content and oil yield of soybean.

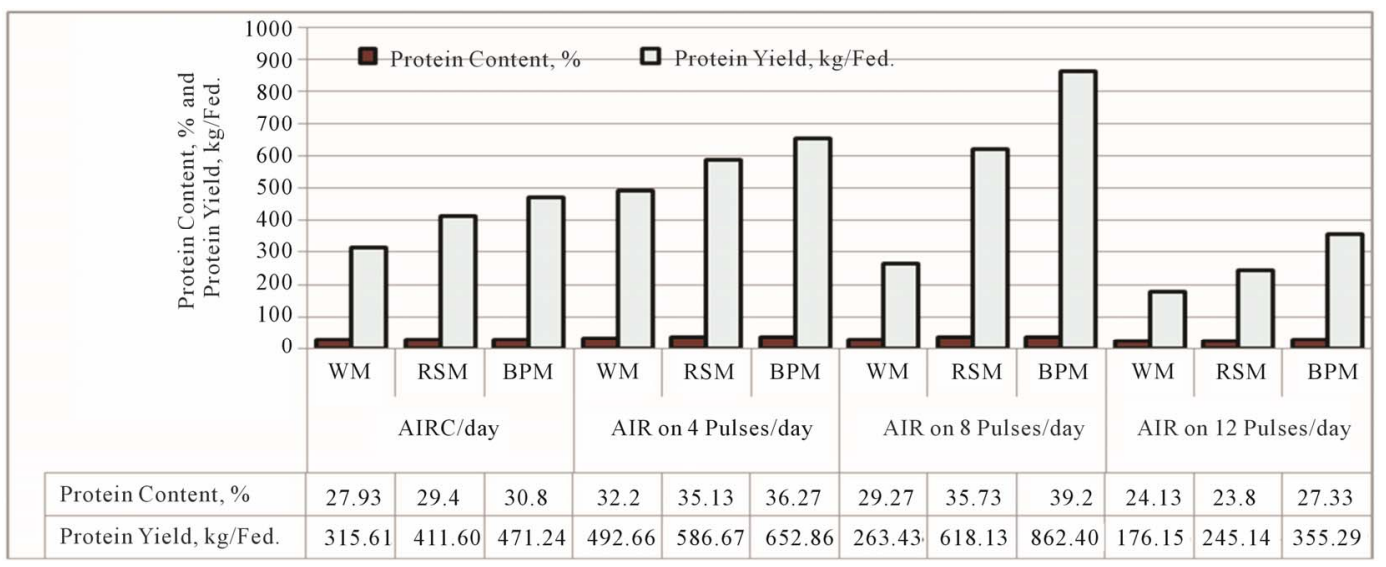

Figure 8. Interaction between pulse drip irrigation and mulching systems on protein content and protein yield of soybean.

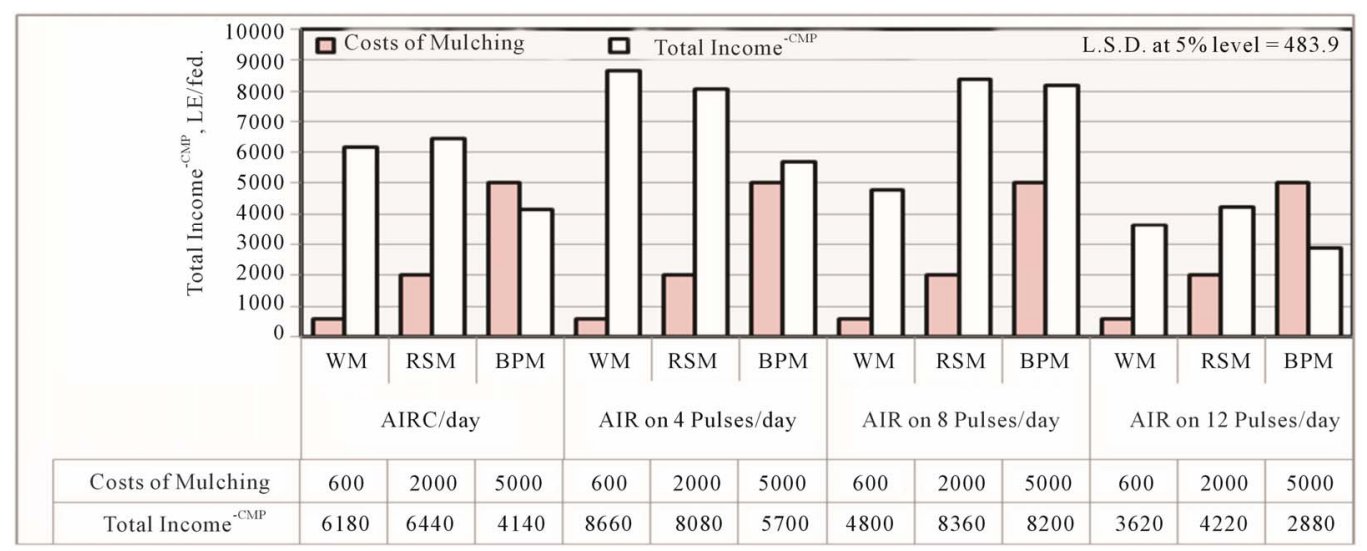

Figure 9. Effect of interaction between pulse drip irrigation and mulching systems on costs of mulching and total income ${ }^{-C M P}$. 
Table 8. Effect of experimental treatments on costs of mulching process and total income ${ }^{-\mathrm{CMP}}$.

\begin{tabular}{|c|c|c|c|}
\hline \multicolumn{4}{|c|}{$\begin{array}{l}\text { Costs of mulching, Total income } \\
\text { LE/fed. }\end{array}$} \\
\hline \multicolumn{4}{|c|}{ Pulsed drip irrigation technique } \\
\hline \multicolumn{2}{|c|}{ AIRC/day } & 2533 & 5586 \\
\hline \multicolumn{2}{|c|}{ AIR on 4 pulses/day } & 2533 & 7480 \\
\hline \multicolumn{2}{|c|}{ AIR on 8 pulses/day } & 2533 & 7153 \\
\hline \multicolumn{2}{|c|}{ AIR on 12 pulses/day } & 2533 & 3573 \\
\hline \multicolumn{2}{|c|}{ L.S.D. at $5 \%$ level } & N.S. & 371 \\
\hline \multicolumn{4}{|c|}{ Mulching systems } \\
\hline \multicolumn{2}{|c|}{ WM } & 600 & 5840 \\
\hline \multicolumn{2}{|c|}{ RSM } & 2000 & 6775 \\
\hline \multicolumn{2}{|c|}{ BPM } & 5000 & 5230 \\
\hline \multicolumn{2}{|c|}{ L.S.D. at $5 \%$ level } & 0.05 & 241.9 \\
\hline \multicolumn{4}{|c|}{ Interaction between pulse drip irrigation and mulching systems } \\
\hline \multirow{3}{*}{ AIRC/day } & WM & 600 & 6180 \\
\hline & RSM & 2000 & 6440 \\
\hline & BPM & 5000 & 4140 \\
\hline \multirow{3}{*}{$\begin{array}{l}\text { AIR on } 4 \\
\text { pulses/day }\end{array}$} & WM & 600 & 8660 \\
\hline & RSM & 2000 & 8080 \\
\hline & BPM & 5000 & 5700 \\
\hline \multirow{3}{*}{$\begin{array}{l}\text { AIR on } 8 \\
\text { pulses/day }\end{array}$} & WM & 600 & 4800 \\
\hline & RSM & 2000 & 8360 \\
\hline & BPM & 5000 & 8200 \\
\hline \multirow{3}{*}{$\begin{array}{l}\text { AIR on } 12 \\
\text { pulses/day }\end{array}$} & WM & 600 & 3620 \\
\hline & RSM & 2000 & 4220 \\
\hline & BPM & 5000 & 2880 \\
\hline \multicolumn{2}{|c|}{ L.S.D. at $5 \%$ level } & 0.06 & 483.9 \\
\hline
\end{tabular}

RSM: Rice Straw Mulch, BPM: Black Plastic Mulch, WM: Without Mulch, AIRC: Appling of Irrigation Requirements Continuously, AIR: Appling of Irrigation Requirements.

4 pulses per day with WM. Although, mulching with black plastic is very expensive but, there are no significant deference between this value $(8660 \mathrm{LE} / \mathrm{fed})$ and $8360 \mathrm{LE} / \mathrm{fed}$ and $8200 \mathrm{LE} / \mathrm{fed}$ with AIR on 8 pulses/day + RSM and AIR on 8 pulses/day + BPM respectively. So, and according to economical view, AIR on 8 pulses/day + BPM is the best conditions because under these conditions was occurred the highest value of soybean yield under the same amount of irrigation water.

\section{REFERENCES}

[1] Eric, S., David, S. and Robert, H. (2004) To pulse or not to pulse drip irrigation that is the question UF/IFAS. Horticultural Sciences Department, Florida.

[2] Helen, R. (2007) Citrus irrigation. Department of Agriculture and Food, Waroona. www. Agric .wa .gov.au

[3] El-Gindy, A.M. and Abdel Aziz, A.A. (2001) Maximizing water use efficiency of maize crop in sandy soils. Arab University Journal of Agriculture Science, 11, 439-452.

[4] Scott, C. (2000) Pulse Irrigation. Water savings Indiana flower growers association. Cooperating with Department of Horticulture and Landscape Architecture Cooperative Extension Service Purdue University West Lafayette, 907-1165.

[5] Segal, E., Ben-Gal, A. and Shani, U. (2000) Water availability and yield response to high-frequency micro-irrigation in sunflowers. The 6th International Micro-irrigation Congress.

[6] Oron, G. (1981) Simulation of water flow in the soil under sub-surface trickle irrigation with water uptake by roots. Agricultural Water Mangement, 3, 179-193. doi:10.1016/0378-3774(81)90002-0

[7] Steyn, J.M., Duplessis, H.F., Fourie, P. and Roos, T. (2005) Irrigation scheduling of drip irrigation potatoes. Northern Province Department of Agriculture, Pietersburg.

[8] Nosenko, V.F., Balabanand, E.I. and Landes, G.A. (1991) Aspects of agrobiological and environmental assessment of irrigation technologies with different volumes of water delivery. Land Reclamation and Water Management. Central Bureau of Scientific and Technical Information.

[9] USDA, FAQ, Elevitch, C.R. and Wikinson, K.M. http://www.nrcs.usda.gov/feature/backyard/Mulching.htm 1

[10] Elevitch, C.R. and Wikinson, K.M. (1998) Greater plant and soil health for less work. Permanent Agriculture Resources, Holualoa. http://www.agroforestry.net/

[11] Abouziena, H.F., Hafez, O.M., El-Metwally, I.M. and Sharma S.D. (2008) Comparison of weed suppression and mandarin fruit yield and quality obtained with organic mulches, synthetic mulches, cultivation, and glyphosate. HortScience, 43, 795-799.

[12] FAOSTAT (2001) Soybean water management. http://www.fao.org/-landandwater/aglw/cropwater/soybea n.stm\#links

[13] Liven, P.C. and Van, F.C. (1979) Effect of discharge rate and intermittent water application by point-source irrigation on the soil moisture distribution pattern. Soil Science Society of America Journal, 43, 5-8.

[14] James, L. (1988) Principles of farm irrigation system design. John Willey\& Sons. Inc., Washington DC.

[15] Stickler, F.C. and Pauli, A.W. (1961) Leaf area determination in grain orghum. Agronomy Journal, 53, 187-188. doi:10.2134/agronj1961.00021962005300030018x

[16] Association of Official Analytical Chemists. (1980) Official methods of the association of official analytical chemists. 11th Edition, Association of Official Analytical Chemists, Washington DC.

[17] Chapman, H.D. and Pratt, R.F. (1978) Methods of analysis for soil, plant and water. University of Georgia, Ath- 
ens.

[18] Snedecor, G.W. and Cochran, W.G. (1982) Statistical methods. 7th Edition, Iowa State University Press, Iowa.

[19] El-Adi, A.M. (2000) Effect of irrigation and fertilization methods on pea production. Misr Journal of Agriculture Engineering, 17, 450-468.

[20] Helmy, M.A., Gomaa, S.M., Khalifa, E.M. and Helal, A.M. (2000) Production of corn and sunflower under conditions of drip and furrow irrigation with reuse of agricultural drainage water. Misr Journal of Agriculture Engineering, 17, 125-147.
[21] Shock, C.C., Flock, R.J., Eldredge, E.P., Pereira, A.B. and Jensen, L.B. (2006) Successful potato irrigation scheduling. Oregon State University Extension Service publication.

http://extension.oregonstate.Edu/catalog/pdf/em/em8911e.pdf

[22] Weeds FAQ Page. Organic weed control methods mulching.

http://faq.gardenweb.com/faq/lists/weeds/200508391902 9708.html 